資 料

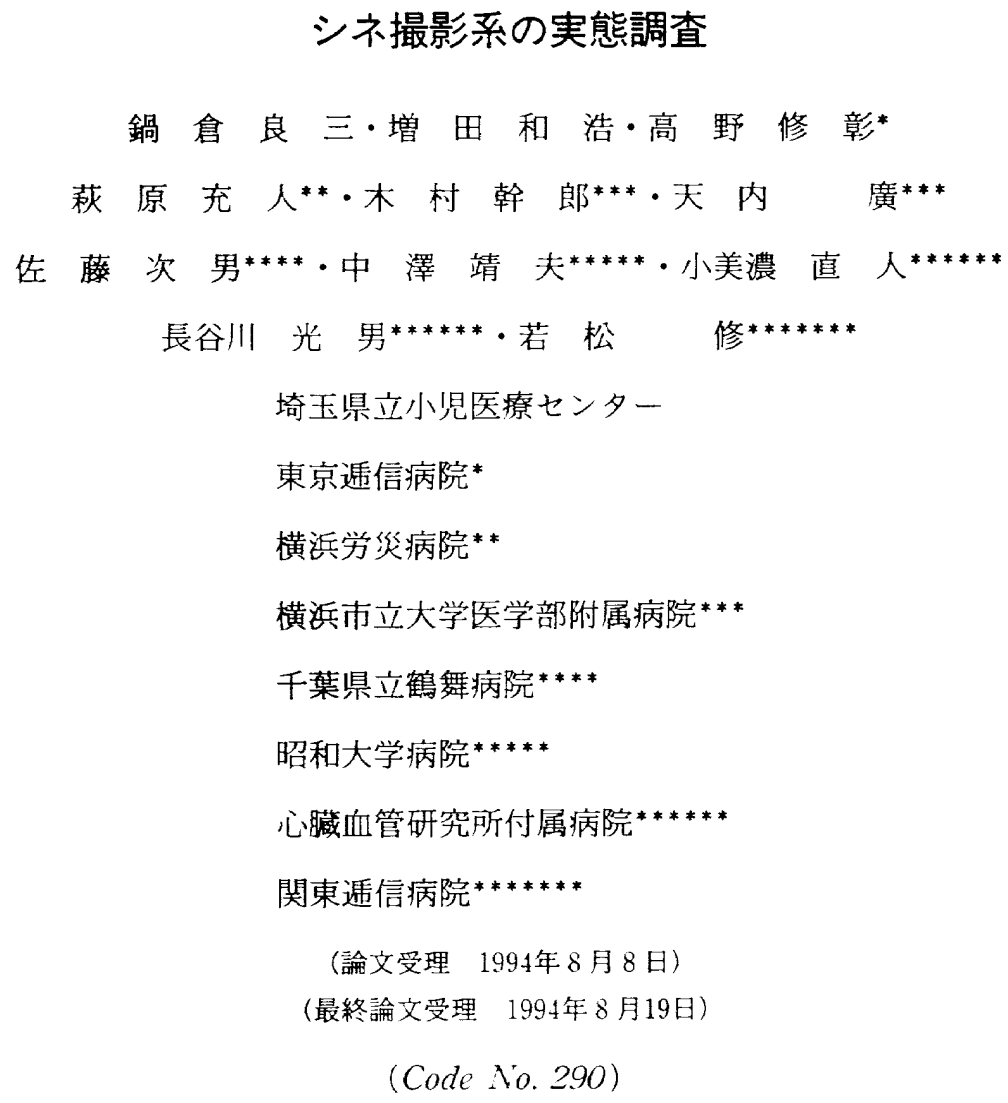

Key words: Questionnaire, Cineradiography, Digital cineradiography, Cardiac angiography, X-ray protection

\title{
A FACT-FINDING STUDY OF CINERADIOGRPHY
}

Ryouzou Nabeklra, Kazlhiro Maslda, Noblaki Takano

Yoshinito Hagiwara, Mikio Kimlera, Hiroshi Amalchi

Tsugio Satol, Yasuo NakazaWA, Naoto Omino

Mitsuo Hasegalla, Osame Wakamatsu

Department of Radiology, Saitama Children's Medical Center

Department of Radiology. Tokyo Teishin Hospital*

Department of Radiology: Yokohama Rousai Hospital**

Department of Radiology. Yokohama City. University Hospital***

Department of Radiology, Chiba Prefectural Tsurumai Hospital****

Department of Radiology, Shouwa Lniversity Hospital ${ }^{* * * * *}$

Department of Radiology: Cardio Vascular Institute Hospital ${ }^{* * * * *}$

Department of Radiolog:; Kantoh Teishin Hospital******

\section{1.はじめに}

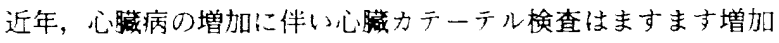

してきている．現在では，PTCA (percutaneous transluminal

coronary angioplasty), PTMC (percutaneous transvenous mitral commissurotomy), Ablation 等の治療分野へも手法が抬 
大され，さらに欠くことの出来ないものとなってきだ．また，デ ジタルシネ装置の開発と進歩によって心減カテーテル検査室の作 業環境も様変りしつつあり, 今やシネフィルムレス化の問題へと 発展してきている2).今回, われわれシネ撮影研究会蛙, 5 年前( $\mathrm{S}$ 62年調查, 以下前回と略）に中沢らが心践カテーテル検査に関す る全国的なアンケート調査 ${ }^{3)}$ をたものの追跡調查を行い, 新た にデジタルシネ撮影に関する設問と小睍シネ撮影の設問を追加し て，その実態を集計したので報告する.

\section{2. 調査方法について}

アンケート調査は, 平成 4 年10月にシネ撮影装置を保有すると 思われる全国シネ撮影技術研究会の会員々無作為に抽出した施設, あわせて500施設に送付した、調査方法は設問によるアンケート調 查とし, 調査期間は過去 3 ケ月間に行われた心蔵力テーテル検査 を対象とした。また，集計方法は，単純加算扔上び単純比率で行 った。

\section{1 調査項目}

2.1 .1 作業環境

作業環境の主な設問は，亿）心カテ検査に携わるスタッフ数,

ロ）カテーテル・アプローチ，八＼cjkstart撮影室の清挲度，二）時間外. 休日の対応，木）定期点検の実施，へ）シネ管理用ファントムの 保有等である。

\section{1 .2 被曝の防護}

被曝の防護の主な設問は，1）被険者の年令分布，口）挨査中 に撮影室の中に入っているスタッフ，八）防護具の使用状況，二） 被検者の生殖腺防護の実施状況等である。

\section{1 .3 デジタルシネ撮影}

デジタルシネ撮影の主な設問は，イ）デジタルシネの導入状況， ロ）デジタルシネの使用方法, 八) デジタルデータの保存記録用 メディア，二）成人冠動脈造影時の画像収集実態（デジタルシネ 導入施設)，木）小晿左心室造影時の画像收集実態(デジタルシネ 導入施設）等である。

\section{1 .4 撮影・透視条件}

撮影・透視条件の主な設問は，亿）自動露出の使用状況，口）撮 影条件 (胸厚 $20 \mathrm{~cm}$ 位の成人左心室と冠動脈造影時), 二) 透視条 件（成人）等である.

\section{1 .5 小児シネ撮影}

小児シネ撮影の主な設問は，亿）撮影条件 (胸厚 $12 \mathrm{~cm} \sim 14 \mathrm{~cm}$ 位の小児左心室造影時)，只）透視条件 (小児)，八）シーンタイ ム (小児) 等である。

2.1.6 現像処理

現像処理の主な設問は，亿）自家現像している施設数，口）シ ネフィルムの使用量，八）現像温度，二）平均階調度等である。

\section{3. 結果および考察}

アンケート調查に対し何らかの回答があった施設は,232施設で 回収率は46.4\%であった。

\section{1 作業環境}

3.1 .1 心力テ挨査に携わるスタッフ数について（Fig. 1) 前回と比較すると，力テ室業務に臨床検査技師と臨床工学士の 参加施設数が増加している。これは，心力テ検査の多様化と臨床 工学士の医療機器への取扱いが法律的に制度化されたことが要因
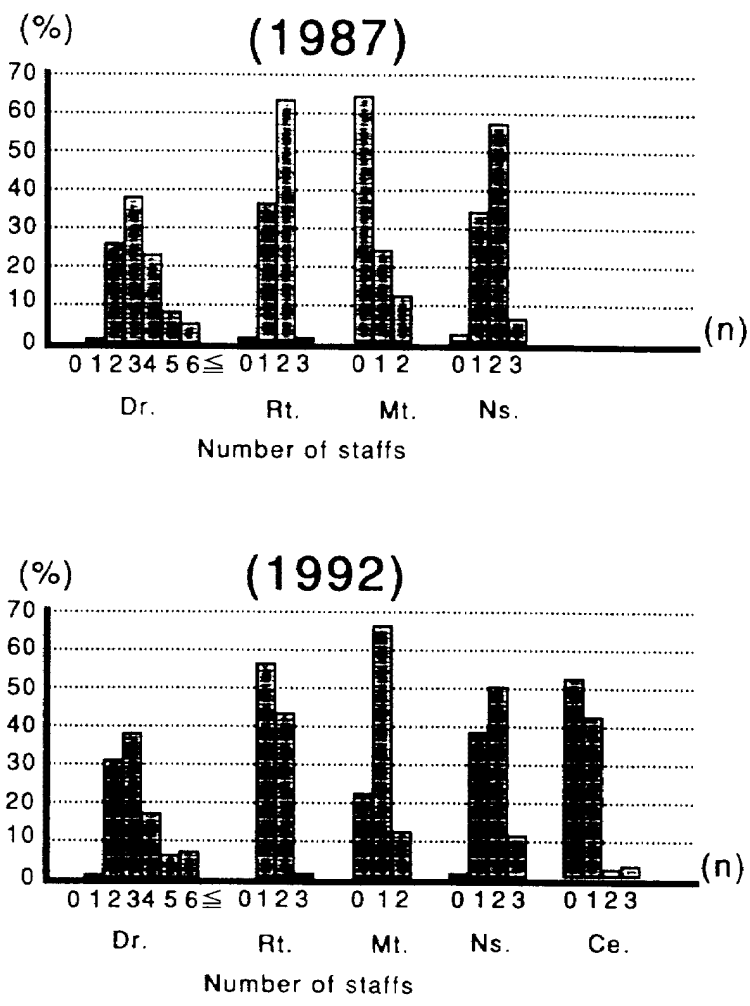

Fig. 1 The result of the inquiry for the number of personnel attending each examination. Dr.: Doctor, Rt.: Radiological technologist, Mt. : Medical technologist, Ns. : Nurse, Ce.: Clinical engineer.

になっていると思われる。

3.1 .2 カテーテル・アプローチについて

穿剌法のカテーテル手技が215施設中199施設（約93\%) であり， ほとんどが穿刺法の傾向を示していた。

3.1 .3 撮影室の清潔度について

215施設中191施設（約89\%）がクリーンルームか準クリーンル 一ムであった。これは，一般の検査室と区別する傾向が表われて きたといえる，施設によっては，手術室同様の清潔度を保ってい ると回答していた。

3.1 .4 時間外・休日の対応について (Fig. 2)

半数以上の施設が当直技師だけで対応できずに心カテ担当者に よるオンコール体制をとっている，この意識としては，䒾置の取 り扱いや心力テ検査か熟練を要する検査であり, 緊急時の対応に もそれ相当の知識か要求されることが原因と考えられる.

3.1 .5 定期点検の実施について (Fig. 3)

定期点検は，前回の謂査に比べて $10 \%$ ほど増えてきており，年 2 回の点検が約半数であった. 平日に定期点険を行っている施設 は54\%であった。昨今は週休 2 日制導入のため, 平日に行ってい る施設が多いが，休日でも定期点検が出来る体制をメーカー側に 望みたり。これは，今後の課題であろう。

3.1 .6 シネ管理用ファントム”の保有について

216施設中62施設（29\%）しか持っていないと回答した。これ は，機器管理の手法が統一されていないこととその煩わしさが影 玮していると思われる。

\section{2 被曝の防護}


(a)

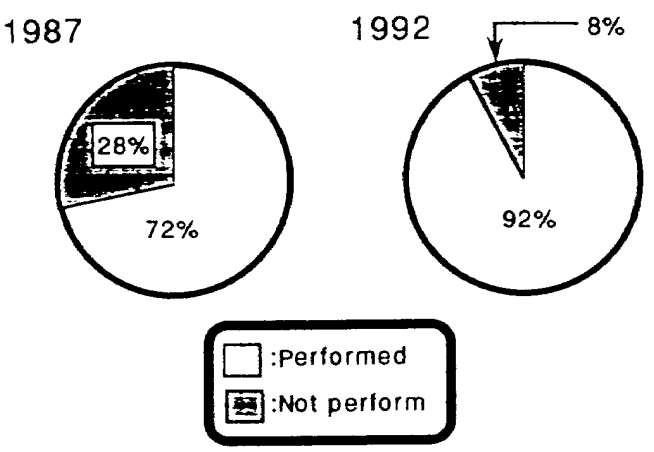

(b)

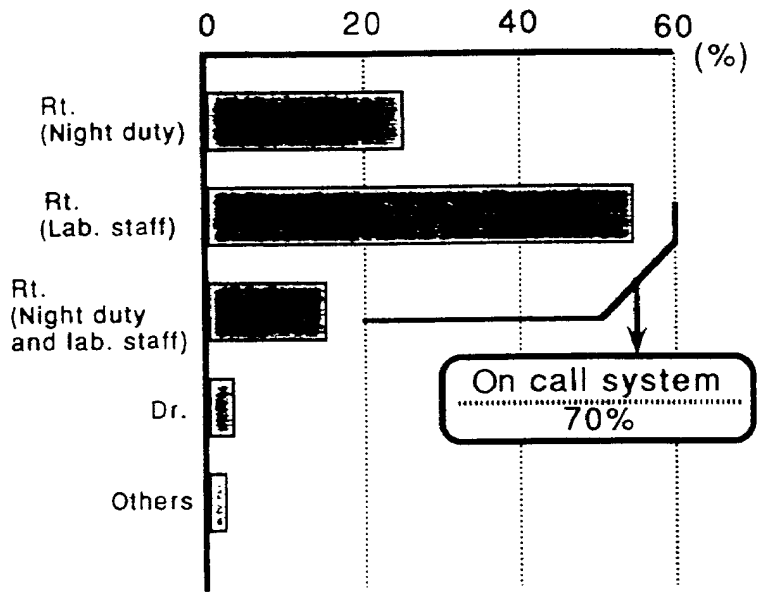

Fig. 2 About the emergency cardiac examination system at night and on holidays.

(a) Number of hospitals in which emergency examinations are performed.

(b) Those who took care of the emergency cineradiographies in 1992 . (a)

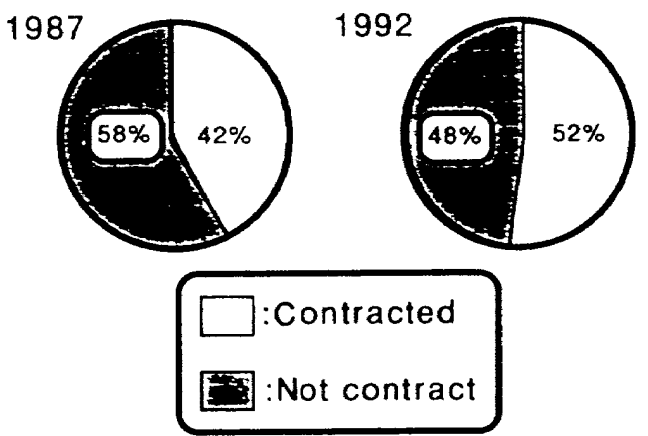

(b)

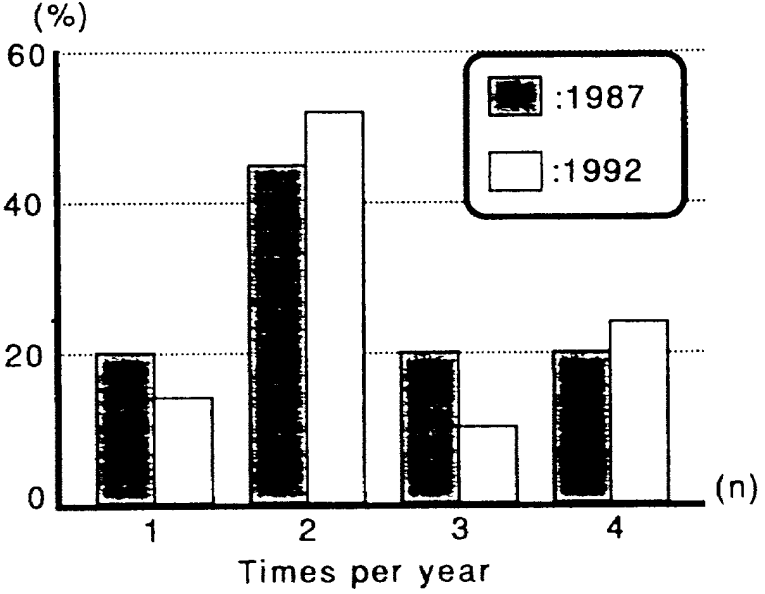

Fig. 3 About periodic inspections of the cineradiogra. phic units.

(a) Number of hospitals that made contracts for periodic inspections.

(b) How often the inspections were performed in a year.

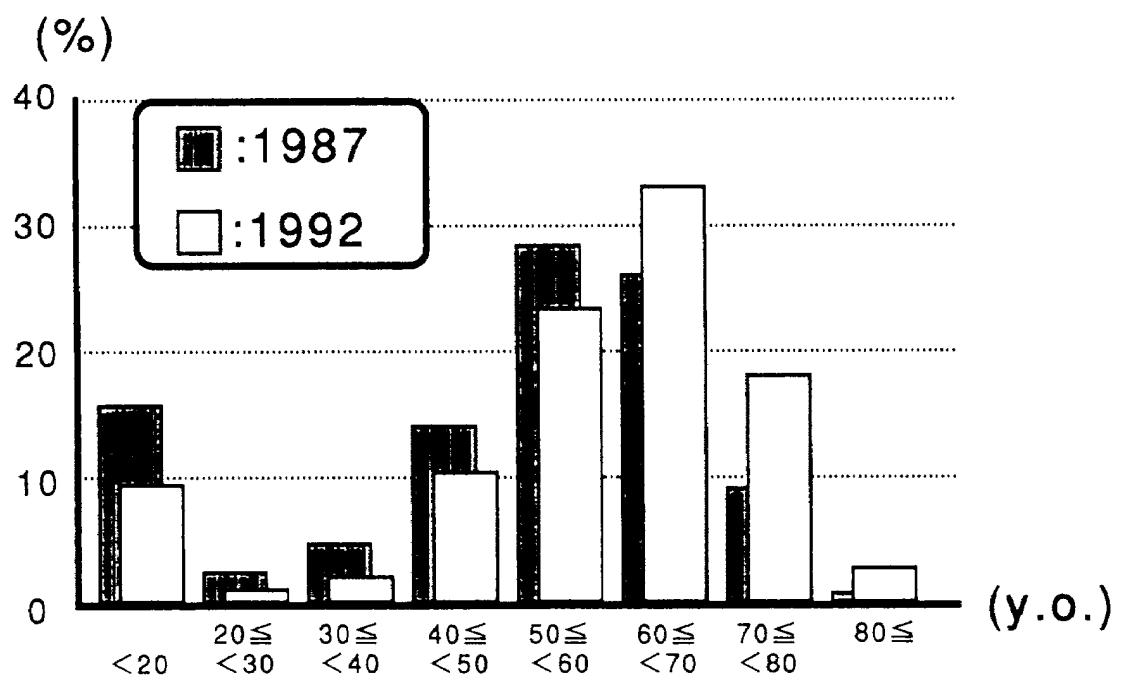

Fig. 4 Patient's age. 
Table 1 Number of hospitals in which someone. other than physicians were in the cardiac examining room while X-rays were being carried out. 158 responses were valid in 1987 and 220 in 1992.

\begin{tabular}{|c|c|c|c|c|c|}
\hline & Doctor & $\begin{array}{l}\text { Radiological } \\
\text { lechnologist }\end{array}$ & $\begin{array}{l}\text { Mctical } \\
\text { lcchrologisl }\end{array}$ & Nursc & $\begin{array}{l}\text { Clinical } \\
\text { engincer }\end{array}$ \\
\hline $\begin{array}{c}\text { Cineradiography in 1987 } \\
(\%)\end{array}$ & $\begin{array}{c}158 \\
(100)\end{array}$ & $\begin{array}{c}86 \\
(54.4)\end{array}$ & $\begin{array}{c}39 \\
(24.7)\end{array}$ & $\begin{array}{l}100 \\
(63.3)\end{array}$ & No questions \\
\hline $\begin{array}{c}\text { Cincradiography in 1992 } \\
(\%)\end{array}$ & $\begin{array}{l}215 \\
(97.7)\end{array}$ & $\begin{array}{c}77 \\
(35)\end{array}$ & $\begin{array}{c}45 \\
(20.5)\end{array}$ & $\begin{array}{l}128 \\
(51.2)\end{array}$ & $\begin{array}{c}17 \\
(7.7)\end{array}$ \\
\hline $\begin{array}{c}\text { Fluoroscopy in 1992 } \\
(\%)\end{array}$ & $\begin{array}{l}220 \\
(100)\end{array}$ & $\begin{array}{c}122 \\
(55.5)\end{array}$ & $\begin{array}{c}60 \\
(27.3)\end{array}$ & $\begin{array}{l}189 \\
(85.9)\end{array}$ & $\begin{array}{c}28 \\
(12.7)\end{array}$ \\
\hline
\end{tabular}

\section{2 .1 被検者の年令分布について (Fig. 4)}

被検者の年令分布は50才代までは前回の方が多かったが，60才 代以上は今回の調査の方が多くなった。これは，心撼疾㭧の高野 者患者の增加と高齢者へのIVR (interventional radiology) 適応 拉大による增加が原因と思われる。

3.2 .2 検査中に撮影室に入っているスタッフについて

検査中に撮影室に入っているスタッフの状況を前回と比較す机 ば，撮影時に撮影室に入っている頻度は減少傾向にあった(Table 1)。乙九被懪低减のために，必要以外は撮影室内加出る上う に心掛けたためと考える。

\section{2 .3 防護具の使用状況（複数回答）について}

プロテクター,ネックプロテクター, 防護衝立, 含鉛メガネの 4 つの防護具が多く使用され，特に術者の医師が前回と比較して 多く使用していた，中でも含鉛メがネは，58施設（36.7\%）から 128施設 $(58.2 \%)$ に，ネックプロテクター仿47施設 $(29.7 \%$ ) か ら185施設 $(84.1 \%)$ 八と約 3 倍にも增えたことが特徴的である。 これは, IVRの普及とともに放射線に対する防護意識が強く表か れてきた結果であり，職業人の意識としては好ましい方向にある といえる。

3.2 .4 被検者の生殖腺防護の実施状況について

実施している施設は，12施設（．．6\%）加ら20施設（9.3\%）と 前回よりやや増加したもののほとんど変化がなかった。これは， その使用が検査手技に影響したり，清潔管理の煩わしさに原因が あるものと考える。

\section{3 デシタルシネ撮影}

3.3 .1 デジタルシネ装置の導入状況について

アンケートの有効回答数217施設中, 92施設 (42\%)でデジタル シネ装䈯を導入していた。また，末導入施設（102施設）に「デジ タルシネ装置は有用と思いますか？」上質問した結果，93施設(約 91\%）が有用上回答した。

3.3 .2 デジタルシネ装置の使用方法について (Fig.5)

シネフィルム撮影とデジタルシネを併用しているという施設が 全体の $75 \%$ （69施設）と一番多く，限られた患者に対してのみデ ジタルシネを併用している施設が $21 \%$ (19施設)，全患者に対して デジタルシネを使用し，限られた患者に対してのみシネフィルム 撮影を件用しているが $1 \%$ ( 1 施設)，そしてシネフィルム撮影を 全く行わない施設が $3 \%$ （3施設）であった。

3.3 .3 デジタルデータの保存記録用メディアについて

92施設のうち78施設の複数回答の結果，約 $46 \%$ の施設で $\mathrm{S}$ -

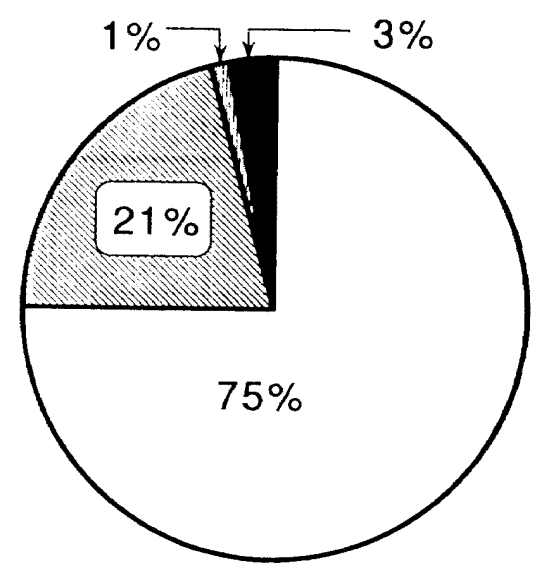

All patients were examined with a cinecamera and digital cineradiographic system : Most patients were examined with only a cinecamera

:Most patients are examined with the digital cineradiographic system

:Digital cineradiographic system only

Fig. 5 Regarding application of the digital cineradiographic system.

Vaid responces were obtained from 92 hospitals.

VHS テーブを使用し，MT(磁気テープ)が約 $12 \%$, SMPTE-D2 テープとFD（フロッピーディスク）がそれぞれ約 $10 \%$ OD (光 デイスク）が約 $6 \%$ ，その他が約15\%使用されていた，各X線装 圆メーカーにより多種多様の記録メディアが使用されている実態 が明的かとなった。

3.3 .4 成人冠動脈造影時の画像収集実態(デジタル装置導入施 設)について (Fig.6)

デジタルシネ装置導入 92 施設のうち有効回答数84施設の集計結 果では，ほとんどの施設 (76施設 約90\%) が512マトリクス，秒 間30フレーム以下で収集していた. 512マトリクス, 秒間60フレー ムでの施設は，3施設（約 4\%）であった。また，1024マトリク ス，秒間30フレームは，5施設(約 6\%)であった。これは, IVR の增加に伴い30フレーム，15フレームの低速レート収集でも可能 であるということを示唆しているものと考えられる。グラフの破 線部分は，装置性能上，512マトリクスでそれぞれの収集レートが 
可能である施設数を表わしているが，収集奏態は必ずしも現有装 置の性能行有を示していないるす上考えられる。

3.3 .5 小児左心室造影時の画像收集実態(デジタルシネ装置尊 入施設) につにて (Fig. 7 )

小罗では全てう12マトリクスでの収集となっていた。高速り收集 レートが必要上さ机る小奣領域で，60フレームで行われている施 設はバイブレーンでて施設(約 $\left.21{ }^{\circ} \mathrm{o}\right)$ ，シングルブレーンでは 9 施 設（約2て\%）にすぎなかった，小児の心族患を目的とするデジ夕 ルシネ装置で画像収集ば”，少量のシャントの同定，心拍数，シ ヤントの血流速度，腎機能等上り考之ると，出来るたけ澧度分解 能，空間分解能，時間分解能つょいバイブレーン取集が必要であ ると考える。しかし，現状では画筫种装䈯の性能等上り，濃度分 解能満たされるとしてき空間分解能と時間行解能は满足できる

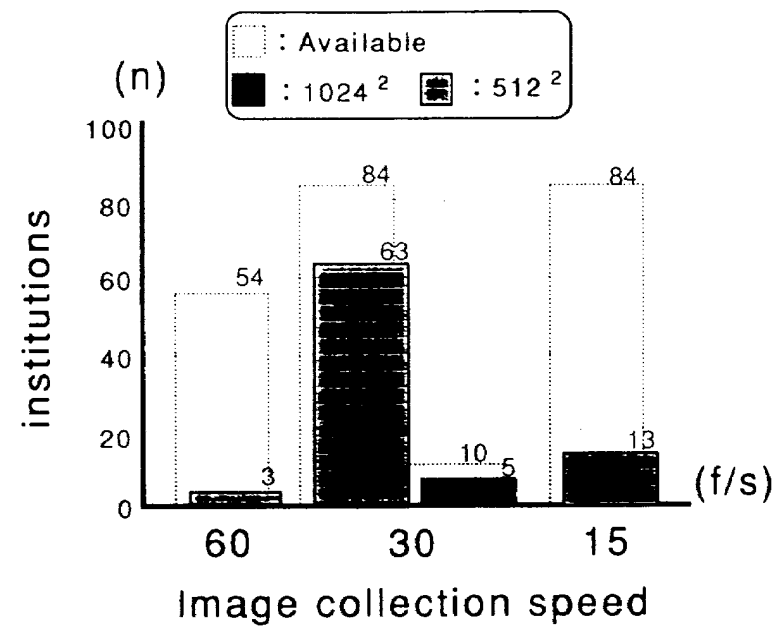

Fig. 6 About how many images per second were obtained regarding digital coronary cineangiographies of adults

8. responces were valid
性能であると泣言い難く、臨床的に可能な範囲で今後検討を重权 て行く必要があるだろうといわれている。．今回のデジタルシネ 装置のアンケート結果より，今㣪のデジタルシネ装置に上る画像 收集は，成人に扔いてはIVRの増加上ももに症例によっては画質 の天い1024マトリクス被曝を考慮した低速レートに䔟行して行 々可能性がある上考えられる。まな小児では，バイプレーンによ る高速度收集が必要であり装置の性能上，可能な限り高いものが 望末札ると考える。

\section{4 撮影・透視条件}

3.4 .1 自動露出の使用状況について

前回092.2\%から98.6\% ○と增加し，ほとんどの施設が自動䘣 出在使用していた。

3.4 .2 撮影条件 (胸悬 $20 \mathrm{~cm}$ 位の成人左心室と冠動脈造影時) こついて

管電匡，バルス幅，I.I. サイズ，撮影時間については前回々同様 う傾向であったが，管電流は，前回よりも高い電流を使用する施 設が増加した（Fig.8)。またフレームレートは，前可よりも低速 レートを使用する施設の増加をみた。

3.4 .3 透視条件（成人）!ついて

透視時の管電圧と透視時間については前回と同様の傾向を示し 心が、透視時の管電流は前回上りも大きくなる傾向を示した(Fig. 9)。デジタルシネ装置やIVRの普及に伴い，今後，モニタ一画像 つ画質の向上を目的とした装置の容量アップとX線入射線量の增 加が危惧されるが，被曝線量にも充分な注意を払って行くべきで あろう。

3.5 小悠シネ撮影

3.5 .1 撮影条件（胸軍 $12 \mathrm{~cm} \sim 14 \mathrm{~cm}$ 位の小児左心室造影時） について

RAO 30 及びLAO60に扔いて撮影電王では60〜69 kV，撮影 電流では300〜399 mA，1フレームあたりの撮影時間では $4.0 \sim 4.9 \mathrm{msec}$, I.I.サイズではて.0〜て.9インチがそれれて机多い数 を占めていた（Fig. 10)。またフフレームレートでも50〜69フレー

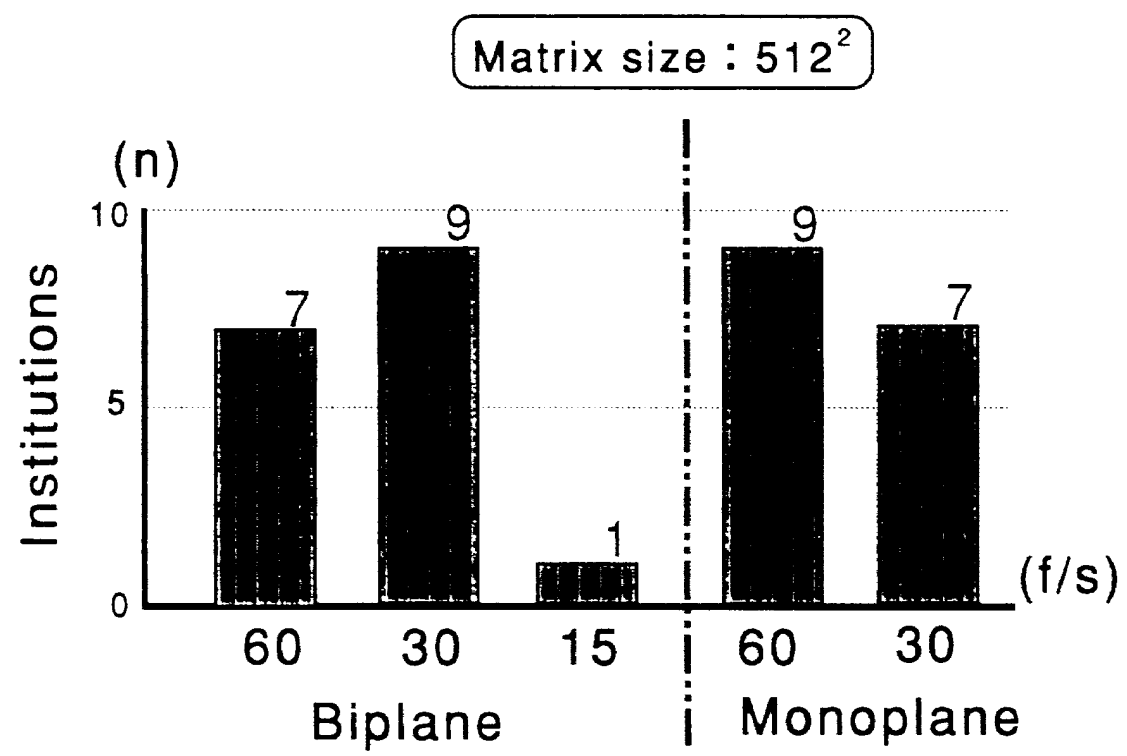

Fig. 7 About how many images per second were obtained regarding digital left ventriculographies of infants. 33 responces were valid. 


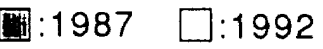
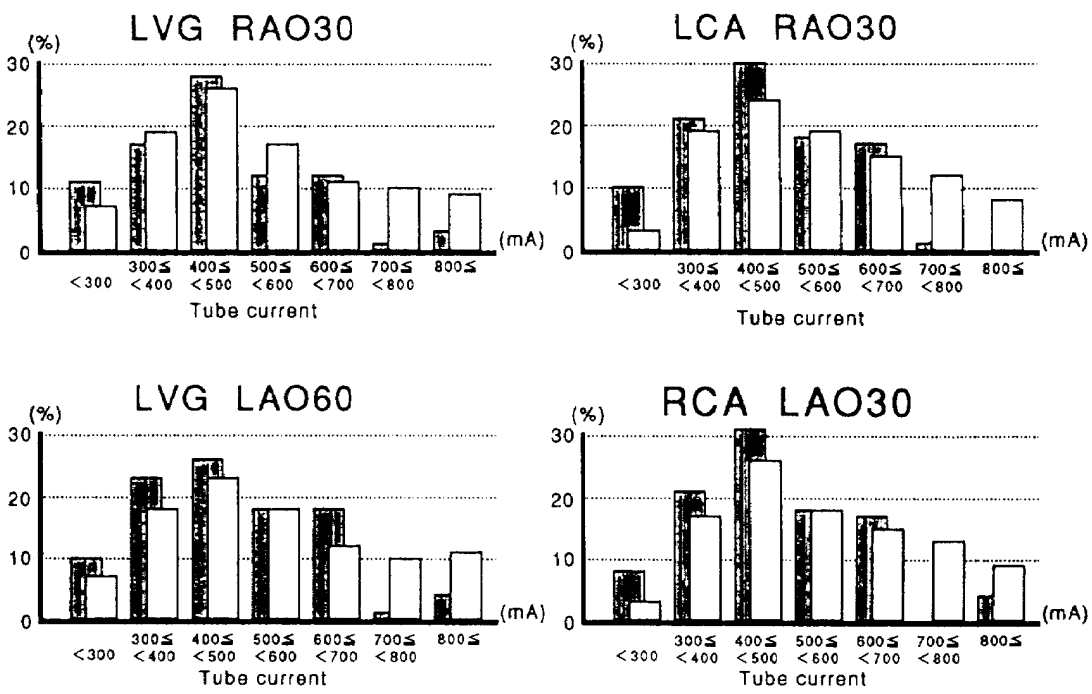

Fig. 8 On tube amperage regarding adult cineradiographies.

(\%)

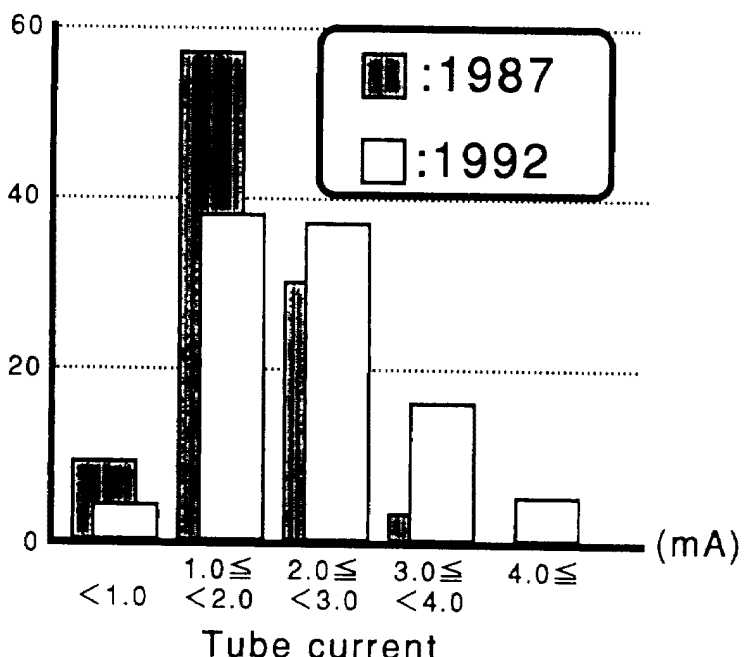

Fig. 9 On tube amperage regarding adult fluoloscopies.

厶が， RAO 30 (67\% 42施設) およびLAO 60 (68\% 40施設) とも多い件数を占めた。

3.5 .2 透視条件 (小児)について (Fig. 11)

透視時の管電圧では $60 \mathrm{kV}$ 台が多く, 管電流は $1.0 \mathrm{~mA}$ 台, 透視 時間は10分台の施設が多かった。また，小児領域へのIVRの影響 と思われる透視管電流の大きい施設や透視時間が30分以上という 施設も数施設あり，小肾の医療被曝上，問題とすべき内容が示さ れた.

3.5 .3 シーンタイム (小児) について (Fig. 12)

小児におけるシーンタイム（1 回造影時のシネ連続撮影時間）

は, 左心室造影, 冠動脈造影, 主肺動脈造影, 右心室造影の4 造 影とも $5.0 \mathrm{sec} \sim 10 \mathrm{sec}$ の間で造影されている施設が多かった。も っとも長く造影している施設は20秒で 3 件ほどあったが，これら の施設では，装置の定格いっぱいまで撮影している可能性があり (n)

(a)

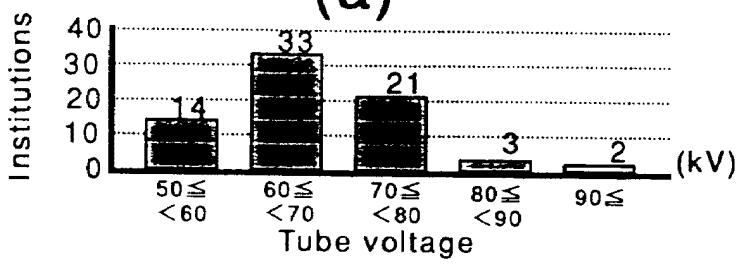

(n)

(b)

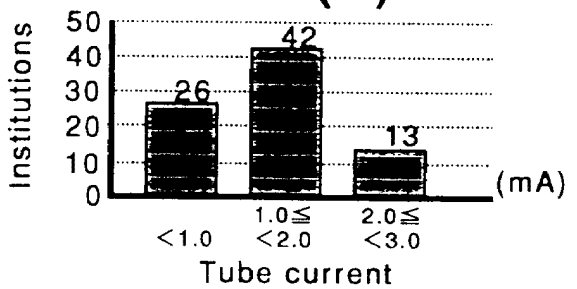

(n)

(c)

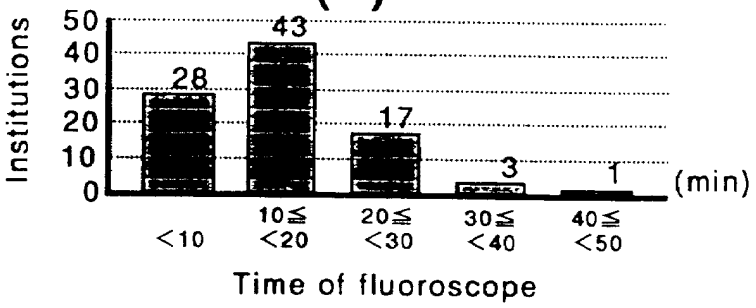

Fig. 11 Dose of fluoloscopic exposure of the cardiac angiography for infants.

(a) Average tube voltage for fluoloscopy.

(b) Average tube amperage for fluoloscpy.

(c) Average time for fluoloscopy

注意が必要であろう。また, 主肺動脈および右心室等の右心系造 影が3.5 sec 以下という施設が数施設あり, これらの施設では, 逆 に小児の心力テに㧍ける循環桨態を撮影するにはシーンタイムが 


\section{T:RAO30 $\square: L A 060$ :others}
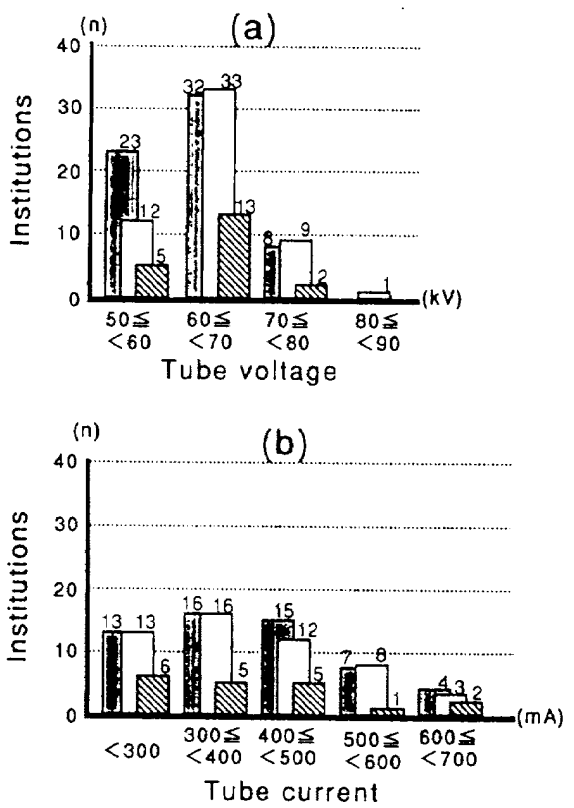

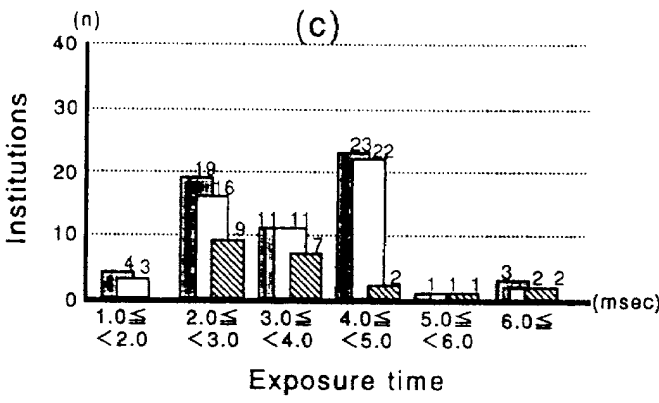

(d)

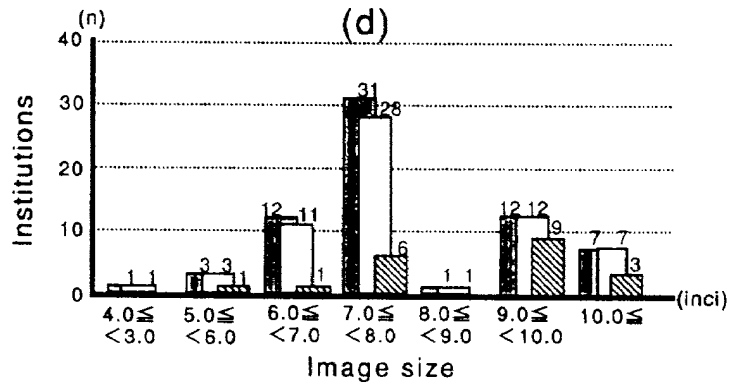

Fig. 10 About the conditions of the cardiac angiography for infants.
(a) Average tube voltage for cineradiography:
(b) Average tube current for cineradiography.
(c) Average exposure time for cineradiography.
(d) Image size for cineradiography

(n)

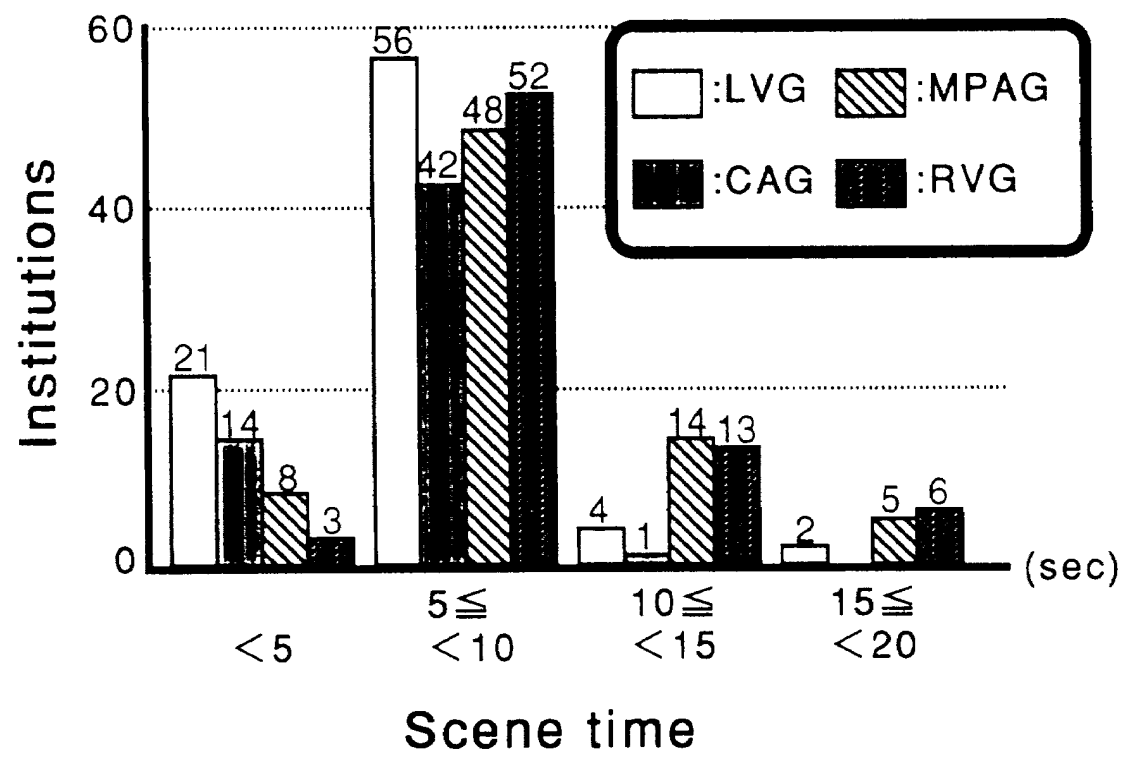

Fig. 12 On scene time of each injection regarding pediatric cardiac angiography.

不十分と思わ机る。

\section{6 現像処理}

3.6 .1 自家現像している施設数について

自施設でシネフィルムの現像（自家現像）を行っている施設は， 前回 $85.1 \%$ (127施設) から今回，95.3\%（205施設）に増加した。
この理由として(1)外注処理の画質への自由度に不满を持っている こと，(2)自動補充機構などの機器改善や処理液の安定性向上によ る現像処理の液管理が安定してきていること, (3)フィルム処理夜 の種類が増えユーーザーの好みの画質づくりが可能となってきた こと，(4)現像の処理法，管理法などの教育，研修が全国的に普及 され，研究会活動の成果が表われてきたこと(5)現像処理系の技術 
(\%)

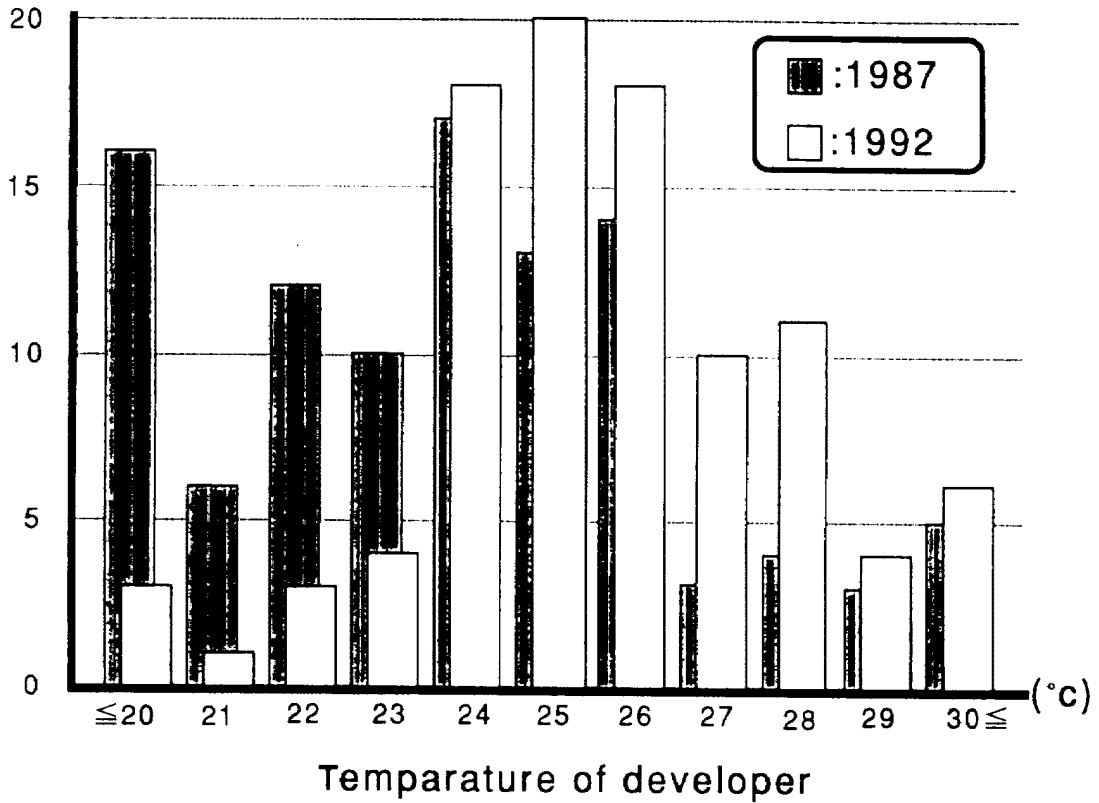

Fig. 13 About the temperature of developer used for cinefilm processing.

$(\%)$

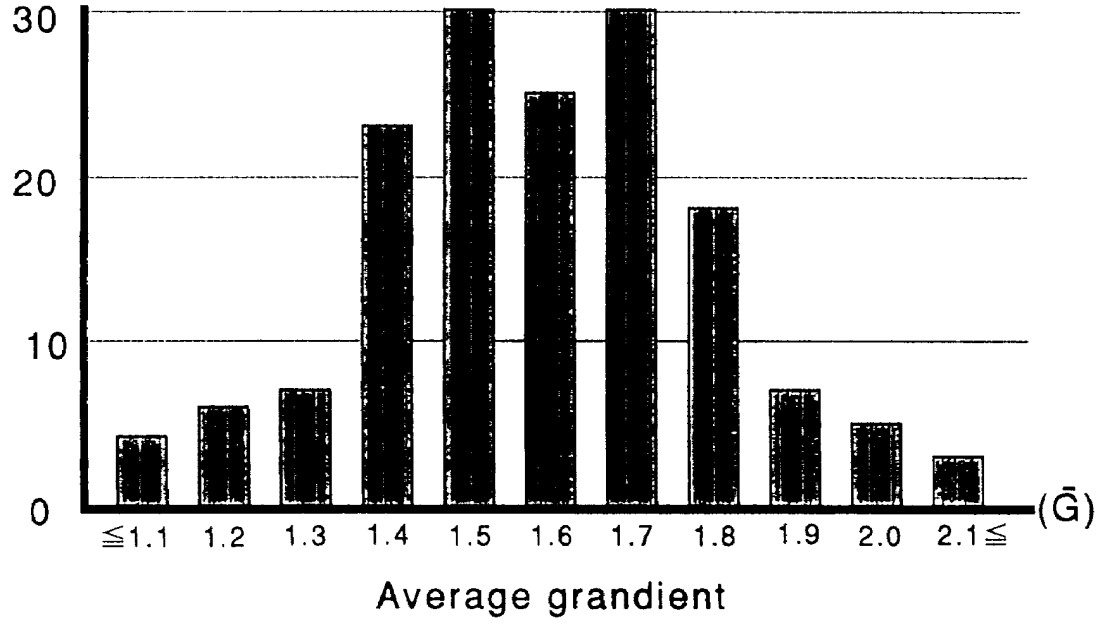

Fig. 14 Average grandient of cinefilm

情報が行き届くようになったこと，などが考えられる。

3.6 .2 シネフィルムの使用量について

1 検査に使われる患者 1 人当たりのシネフィルムの使用量は, 200 feet 以上， 350 feet 未満の施設が約60\%（115施設）を占め た。これは，総撮影回数が隇ったことや低速レートの撮影に伴っ て，1検査に使われる患者 1 人当たりのシネフィルムの使用量が 隇少しているものと思われる。

\section{6 .3 現像温度について（Fig. 13）}

前回の調查と比較して，現像温度は高温処理の方向に移動した 結果を示した。これは, 最近の低感度微粒子タイプのシネフィル ムの登場によって現像温度が高温処理に移行したか，あるいは高 温・高速処理によって短時間にシネ画像を臨床に提供したいとい うユーザーの意志が反映した結果ではないかと推定する。

3.6.4 平均階調度について (Fig. 14)
平均階調度 $(\bar{G})$ は，1.4〜1.8の間が約 $80 \%$ (158施設) を占め ていた。シネフィルムの感度や階調は，各施設で使用しているシ ネフィルムの種類や装置の出力の違い, あるいはデジタル画像と の関連などから多様な現像処理特性を示すものと思われたが，比 較的限られた平均階謂度の範弗で現像処理がなされている実態が 明らかとなった。この平均より外れた処理を行っている施設とし ては，極端に階調度が低い施設（ $\bar{G}=1.1 \sim 1.3 ， 17$ 施設，約 $11 \%)$ と揣端に高い施設（ $\overline{\mathrm{G}}=1.9 \sim 2.1 ， 15$ 施設，約 $9 \%$ )があった，階 調度が低い施設は，デジタルシネ画像との画質の関連が考えられ， 階調度が高い施設は画像観察システムとの関連が考えられそれら を考慮しなければならない。

$$
\text { 4.まと め }
$$

機器管理は，管理用ファントムを30\%の施設でしか保持してお 
らず，定期点换の実施状況上考えあわせるとまだ不十分な実態と 言える。

デジタルシネ装置に関しては，今やIVRにはなくてはならない 機能となっているが，さらに信頼性を高めもつと普及させるため には保存用記録メディアのデータフォーマットの統一性やその記 録容量，操作性，価格面，診療報酬等の諸問題が解決されること が必要と思われる。

小児シネ撮影は，特に透視時間や撮影のシーンタイムに対して 医療被懪の見地から一考を要すると思われる。

装置容量とX線入射線量の実態では，撮影管電流が前回よりも 高い電流を使用している施設が增えており，今後もさらに大電流 の装置が導入されていくだうと言われている゙.しかし，IVRに 対する使用や装置の容量アップと共にX線入射線量の増加も危惧 されており，被曝線量には十分に留意すべきであろう。

現像処理系の実態では，自施設で現像を行なう施設が前回より 增加傾向にあり，シネフィルムの現像処理技術や知識の向上等が 進んだ結果と思もれる。

今回のアンケートの結果，心炡カテーテル検査の時間外・休日 険榃沁心カテ室の專任技師がオンコールで応需している施設が大 半であるという丰態が明らかとなり，一般的にシネ撮影業務が専 門性の高い業務であると認識されていることが裹付けられた，今 後，担当技師の教育のあり方を考える上で基礎になるものと考え る.

\section{5. 謝辞}

アンケート調查にご協力頂きました全国各施設に深謝申し上げ ます。また，研究員の活動に特段のご配慮を賜った各施設の技師 長はじめスタッフの方々そしてご指導いただいた埼玉県立小児医 療センタ一放射線部前技師長橋本宏氏に深く感謝申し上げます。 なお，本論文の要旨は，第49回総会および第21回秋季学術大会に おいて発表したものです，最後に本研究は，日本放射線技術学会 東京部会の「研究テーマ助成金」を受けて行うことができ，日本 放射線技術学会東京部会長はじめ関係各位に厚くお礼を申し上げ ます。

\section{6. 文献}

1）相澤忠範：PTCAの現況と今後の動向.シネ撮影研究， 9,12 -15, (1993).

2）三和秋雄：シネフィルムレス化の現状と展望。全国シネ撮影 技術研究会誌，4，79-92，(1992）。

3）中澤靖夫, 加藤京一, 山本桂一, 他：心藏カテーテル検査の 実態と被曝線量測定. シネ撮影研究，7，3-17，(1991)。

4）佐藤次男, 传藤律夫, 若松 修, 他：シネ撮影用総合ファン トムの作製，日放技学誌，36(12)，1396-1428，(1989).

5）鍋倉良三：先天性心疾患とデジタル画像の取り込み技術につ いて。全国シネ撮影技術研究会誌，5，91-96，(1993)。

6）增田和浩：循環器系 X線撮影システムの進步。映像情報，1, 56-61, (1991).

7）宮崎 茂, 原 孝光, 松谷一雄, 他：インバー夕式X線装置 の短時間特性。日放技学誌，50(4)，497-504，(1994). 